\title{
FORMATION OF INDIVIDUAL INFOLOGICAL MODELS OF PERFORMANCE MANAGEMENT SYSTEMS
}

\author{
Dmitry V. ISAEV \\ Associate Professor, Department of Business Analytics, \\ National Research University Higher School of Economics \\ Address: 20, Myasnitskaya Street, Moscow, 101000, Russian Federation \\ E-mail:disaev@hse.ru
}

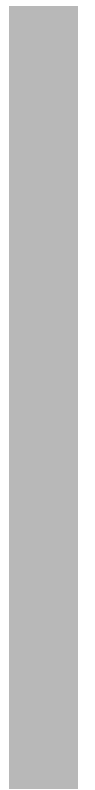

The paper focuses on the questions of infological modeling of performance management systems (PMS), which represent the means of information support of strategic management and help to eliminate the gaps between strategic and operational management levels. Infological models of performance management systems include such elements as information flows, external information objects, functional blocks, functional modules, analytical functions, as well as methods, information systems and processes of management information processing.

It is preferable to develop individual infological models for particular organizations relying on reference models, by individualizing them and detailed elaboration. Among the reference models, there is a basic (generic) infological model that represents the most common characteristics of all the enterprises and organizations, regardless their types and industry affiliation.

The procedure of transition from the basic infological model to an individual model includes four stages.

In the first stage, detailed elaboration of enlarged information flows is performed: each of the enlarged information flows is subdivided into more detailed flows, taking into consideration the peculiarities of a concrete organization. The detailing is provided taking into account types and sources of information, as well its affiliation with particular divisions, business segments and geographical segments. In the second stage, relationships between inputs and outputs of functional modules are discovered. Relying on such relations, preliminary (necessitating additional specification) analytical functions are established. In the third stage, the processes of collection, storage and processing of management information that are available within preliminary analytical functions are defined. Finally, in the fourth stage, the final versions of analytical functions are created by detailing and re-organization of previously defined preliminary functions.

The paper also indicates the possibility of an alternative approach, where developing an individual model starts with the definition of analytical functions.

Key words: performance management system, infological modeling, reference model, individual model, analytical function, information flow, management information processing.

Citation: Isaev D.V. (2015) Formation of individual infological models of performance management systems.

Business Informatics, no. 4 (34), pp. 32-37. DOI: 10.17323/1998-0663.2015.4.32.37.

\section{Introduction}

$\mathrm{P}$ erformance management systems (PMS) represent one of the important classes of management systems. Nowadays they are applied in many large companies and non-for-profit organizations. In the most common sense, such systems may be defined as «formal and informal mechanisms, processes, systems, and networks used by organizations for converting the key objectives and goals elicited by management, for assisting the strategic process and ongoing management through analysis, planning, measurement, control, rewarding, and broadly managing performance, and for supporting and facilitating organizational learning and change» [1]. However, performance management systems often are treated in some narrower sense - as means of information support of strategic management which help to eliminate gaps between strategic and operational management levels [2-4].

One of the stages of performance management systems development process is the stage of design, which includes 
formation of infological models. The importance of such models is explained by the fact that they are used as a foundation for subsequent detailed design of particular subsystems and for planning their development. In this connection, an approach to the formation of individual infological models seems topical. Any individual infological model refers to a specific entity and should take into consideration its characteristics - both sectoral and individual.

\section{Reference and individual infological models of a performance management system}

The methodology of infological modeling of performance management systems has many similarities with other modeling approaches, but at the same time is oriented to a particular task. Such methodology reflects all the material aspects that are important for subsequent design of subsystems. On the other hand, the methodology allows us to avoid excessive detailing, which may reduce understandability of the models for wide range of stakeholders, and first of all, - for managers and specialists who work in the relevant management areas.

The basic terms of the performance management systems modeling methodology include [5]:

$\downarrow$ information flow - a distinguishable part of management information that is to be transmitted between, at least, two information objects - the source of the information and its recipient;

$\downarrow$ external information object - a source or a recipient of information, which is situated outside the performance management system;

$\checkmark$ functional block - an enlarged information object of the performance management system;

$\checkmark$ functional module - an information object of the system, which is situated within a functional block;

$\checkmark$ analytical function - an information object of the performance management system which is situated within a functional module. Each analytical function has its owner - a department that supervises its execution;

$\checkmark$ method of information processing - a way of transforming an input of an analytical function into its output;

^ information system - hardware and software that provide practical application of an appropriate information processing method;

$\checkmark$ process - a set of operations that are necessary to transform an input of an analytical function into its output. Each process has its owner, as well as performers of certain operations.

The formation of individual (i.e. related with concrete organizations) infological models of performance management systems may be executed either «from scratch», or relying on typical (reference) models reflecting characteristics of a certain range of management objects.

Within possible reference models, a basic (generic) infological model of the performance management system may be considered to be the most important. The model represents common characteristics of all the organizations, regardless of their types and industry affiliation. The basic model uses a restricted range of modeling elements - information flows, external information objects, functional blocks and functional modules. In particular, the model includes five enlarged external information objects, four functional blocks, thirteen functional modules, as well as information flows between them [6].

The basic model has an enlarged nature: it covers neither detailed analytical functions, nor data processing methods, systems and processes. Furthermore, information flows and external information objects are also enlarged and are subjects of subsequent detailed elaboration in the individual infological models.

Besides the basic infological model, industry-focused reference models may be applied. The industry-focused models reflect specific characteristics of certain industries or types of organizations. Such models are more detailed in comparison with the basic model, because they deal with detailed information flows and external objects.

As to individual infological models, they should contain all the elements of modeling methodology, including detailed information flows, detailed elements of external information objects, as well as analytical functions (with their owners), methods, information systems and processes (with their owners and executors of their operations).

\section{Transition from the basic infological model to an individual model}

The formation of an individual infological model of a performance management system relying on the basic (generic) model is related to the execution of four stages.

Stage 1. Detailing of enlarged information flows. At this stage, each of the enlarged information flows of a basic model is represented as a set of more detailed flows that represent specific features of concrete organizations. Under the detailing such aspects as the type of information, as well as its affiliation with certain divisions, business segments and geographical segments should be taken into consideration.

The type of information characterizes its nature and its role in the management system. In many cases, types of 
information may be determined relying on the applied methods and models of economic analysis and management, for example, environmental analysis models, balanced scorecard methodology, decision making methods, budgeting theory, financial consolidation standards, etc. Often it is convenient to represent the classification of information types as a hierarchy, using «from the general to the particular» logic. Taking into consideration the objective differences in the nature and purpose of the information, different types of information should be represented by different detailed information flows (although one information flow may be used by several recipients).

By a division with which one or another information flow is affiliated, we imply a large element of an organizational structure - a strategic business unit, an enterprise (within a group of companies), or a large department. If the information refers to different divisions, it should be separated into different detailed information flows. The exception is the case when information processing is centralized and the results are delivered simultaneously to several divisions.

A business segment is a component of an entity that provides a particular product, or a group of related products. Identification of business segments may rely on such criteria as the nature of a manufactured product, features of production process, types of customers and methods of delivery, as well as the specificity of the regulatory environment.

Affiliation with a business segment may have an influence on applied types of information, because different businesses need management information of different nature. For example, technological information is important for all the business segments; however, different business segments use information about different technologies. This means that some types of information are relevant to certain business segments and at the same time irrelevant to the others. If information types are represented as a common hierarchical classification, discrepancies may arise on any of the levels. It is also possible to use an approach where particular classifiers are developed for each of business segments separately. At the same time, some types of information are equally relevant to all the business segments (for example, general legislation).

Information relating to different business segments should be represented by different detailed information flows; it is provided by relevancy of information types to certain business segments.

A geographical segment is a component of an entity that provides products or services within a particular economic environment which is inherent to a particular re- gion. The distinction of geographical segments may rely on such considerations as features of economic and political conditions in regions, relevant risks, as well as relationships between operations in different regions.

Affiliation with geographical segments is also topical for some types of information. For example, marketing information is important for all the geographical segments, however, in different segments information about different regional markets will be used. Affiliation with a geographical segment does not affect the applied types of information: similar operations in different geographical segments require information of the same types. As in the case of business segments, some types of information are equally relevant to all the geographical segments (for example, technological information).

Information relating to different geographical segments should be represented by different detailed information flows.

Stage 2. Establishing linkages between inputs and outputs of functional modules, determining preliminary analytical functions. As for outgoing information of functional modules is created relying on incoming information, at this stage correspondence between inputs of modules and their outputs is established. For each output, a search of inputs whose information (taking into account its processing) is necessary for this output is arranged. Moreover, each output should correspond to at least one input, and each input should be linked with at least one output.

Particular processes of incoming information processing are not considered at this stage. However, methods and appropriate information systems, which will be used to transform inputs into outputs, are to be defined. Determination of methods and data processing systems is extremely important at this stage, because they in many respects have an effect on correspondence between inputs and outputs.

When establishing correspondence between inputs and outputs of functional modules, two types of problem situations may arise.

In the first case, for some of the outputs, determining appropriate sets of inputs (so that information of these inputs will be sufficient for formation of the outputs) appears unsuccessful. The cause is insufficiency of the incoming information. In this case, it is necessary to revise the scope and content of the incoming information flows, and then - to introduce some new information flows or to amend content of existing ones.

In the second situation, for some of the outputs aggregated incoming information arriving from corresponding inputs is excessive, but still all these inputs are really necessary and none may be excluded from considera- 
tion. Such a situation may arise from a lack of information flow detailing. In this case, it is necessary to arrange additional detailed elaboration of incoming information flows which are excessive regarding certain outputs.

After establishing the correspondence between inputs and outputs of functional modules, relying on these linkages, analytical functions are formed. Each of these functions, as usual, is related to one particular output of the functional module: each function receives incoming information that, after certain processing, is transformed into outgoing information for the particular output of the functional module.

The exceptions are cases when several outputs are created as a result of joint information processing. In such cases, an analytical function may be related simultaneously with several outputs.

The scope of analytical function determined at this stage is not final, because they were established just relying on linkages between inputs and outputs, regardless of concrete processes of information collection, storage and processing. Furthermore, one has to define more precisely the scope of the function and their content, taking into account particular processes and their owners. Therefore, the analytical functions determined at this stage may be treated as preliminary functions.

Stage 3. Determining processes of management information gathering, storage and processing within preliminary analytical functions. At this stage, within preliminary analytical functions, we describe processes of transformation of these functions' inputs into their outputs. When describing the processes, previously defined data processing methods and information systems are taken into consideration. The processes are described using existing notations such as ARIS, IDEF 3 or BPMN. In a parallel way, the methods and information systems are elaborated in more detail. For all the defined processes (or their considerable fragments), their owners (departments and managers responsible for execution of the processes) are appointed.

At this stage, cases of duplication of the processes (i.e. execution of the same processes within different analytical functions), as well as situations when processes of one analytical function have different owners are quite probable. Such situations arise because of the peculiarity of the procedure of determining preliminary analytical functions and they should be adjusted in the next, final stage.

Stage 4. Determining final analytical functions. The fourth and final stage is associated with redesign of preliminary analytical functions and determining final versions of the functions. Moreover, the preliminary func- tions are analyzed from the point of view of duplication of processes. All the processes and their considerable parts, which are duplicated within one or several preliminary functions, are to be excluded from these functions. Instead, for each such process (fragments) a new analytical function is created. As a result, preliminary analytical functions are transformed into new functions that are free from duplication of processes.

After elimination of the process duplication effect, analytical functions are analyzed from the point of view of the existence of multiple owners of the processes which are available within them. Such situations are undesirable because the existence of multiple owners within the same function may appear critical for appointment of the owner of the analytical function. Therefore, in such cases it is recommended to split the analytical function into a few new functions, so that all the processes within any of the new functions have only one owner (that becomes the owner of the whole function).

The combination of different processes owners within one analytical function is acceptable as an exception if the vast majority of the processes within the function are associated with the same owner. In this case, such an owner is appointed as the owner of the whole analytical function, while «minority» owners act as its subcontractors.

At the fourth stage, the direct performers of all the operations of the processes are also appointed. Generally, the performers of certain operations may differ from the owners of processes and analytical functions.

\section{An alternative approach}

As an alternative to the procedure of transition from the basic infological model to an individual model described above, an approach starting with analytical function determination may be considered. The scope and content of analytical functions should be determined relying on two criteria - commonality of operations performed within one or another function, and the possibility to appoint a certain owner who is able to take responsibility for execution of the function. For each determined analytical function, its inputs and outputs, as well as the methods of management information processing and appropriate information systems should be defined.

Further steps are focused on determining information linkages between analytical functions and, for external information flows - between analytical functions and external information objects. This means that each input of an analytical function should be linked with a single source - an output of another function or external object, and each output - with outputs of other functions 
or external objects. For this purpose, first of all, correspondence of inputs and outputs of analytical functions with functional modules and external objects (information sources or recipients of the function) is performed. At the same time, enlarged information flows related to inputs and outputs of analytical functions are defined. These steps allow us to link analytical functions and, if necessary, external objects and, consequently, to determine detailed information flows.

Using this approach, some problems related with identification of linkages between inputs and outputs of analytical functions may arise. It is also possible that some of the information requirements of external objects - recipients of information from the performance management system appear unfulfilled. The cause of such situations may be related to lack of content of information flows, or even to missing some information flows that really are necessary. Such discrepancies may arise when determining inputs and outputs of analytical functions. Adjustment of problem situations arising during the alternative approach application may require either revision of content of the information flows (and, consequently, inputs and outputs of analytical functions), or addition into the model of some new information flows or new analytical functions.

Adjustment of the model may have an iterative nature and may require considerable investment of the time of managers and specialists. Nevertheless, the advantage of the alternative approach is the possibility of better use of knowledge, experience, initiative and enthusiasm of employees who work on lower levels of the management hierarchy, while determining the ways of performing managerial functions more efficiently. In contrast to the main approach described above («from the requirements»), the alternative approach may be considered as an approach «from possibilities». It may be concluded that both approaches may be applied in the practice of modeling performance management systems.

\section{Conclusion}

Infological modeling is extremely important for designing performance management systems and, in the general context, - for managing the development of such systems. The infological model is based on such elements as information flows, functional blocks, functional modules, analytical functions, as well as methods, information systems and processes of management information processing.

While the basic (generic) reference infological model of a performance management system represents the most common characteristics of organizations of all types and industries, individual models are designed for particular organizations. The most efficient way of forming individual infological models is transition from the basic reference model by its detailed elaboration. The procedure of an individual model formation relying on the basic model comprises several stages, including detailing of enlarged information flows, establishing linkages between inputs and outputs of functional modules with subsequent determination of preliminary analytical functions, determining processes of management information gathering, storage and processing within preliminary analytical functions, and determining final analytical functions.

There is also an alternative approach. According to this approach, the first step of the individual infological model formation process is definition of analytical functions. Then correspondence between analytical functions and external information objects are established and detailed information flows are determined. The alternative approach allows us to use competences of management personnel more efficiently and, in spite of some objective disadvantages, may also be applied in modeling practices of performance management systems. Detailed elaboration of stages of the alternative approach, as well as related problem situations, may be considered as a subject of further research.

\section{References}

1. Ferreira A., Otley D. (2009) The design and use of performance management systems: An extended framework for analysis. Management Accounting Research, no. 20, pp. 263-282.

2. Cokins G. (2004) Performance management: Finding the missing pieces (to close the intelligence gap). Hoboken, NJ: John Wiley \& Sons.

3. Coveney M., Ganster D., Hartlen B., King D. (2003) The strategy gap: Leveraging technology to execute winning strategies. Hoboken, NJ: John Wiley \& Sons.

4. Eckerson W.W. (2006) Performance dashboards: Measuring, monitoring and managing your business. Hoboken, NJ: John Wiley \& Sons.

5. Isaev D.V. (2013) Proektirovanie sistem informatsionnoi podderzhki korporativnogo upravleniya i strategicheskogo menedzhmenta [Design of corporate governance and strategic management information support systems]. Audit and Financial Analysis, no. 6, pp. 329-334.

6. Isaev D. (2012) Performance management information support system: A conceptual model. European Journal of Economics, Finance and Administrative Sciences, no. 52, pp. 6-20. 


\title{
ФОРМИРОВАНИЕ ЧАСТНЫХ ИНФОРМАЦИОННО-ЛОГИЧЕСКИХ МОДЕЛЕЙ СИСТЕМ УПРАВЛЕНИЯ ЭФФЕКТИВНОСТЬЮ
}

\author{
Д.В. ИСАЕВ \\ кандидат экономических наук, доцент кафедры бизнес-аналитики, \\ Национальный исследовательский университет «Высшая школа экономики»
}

Адрес: 101000, г. Москва, ул. Мясницкая, д. 20

E-mail:disaev@hse.ru

Статья посвящена вопросам информационно-логического моделирования систем управления эффективностью (performance management systems, PMSs), представляющих собой средства информационной поддержки стратегического менеджмента, помогающие устранить разрывы между стратегическим и текущим уровнями управления. Информационно-логические модели систем управления эффективностью включают такие элементы, как информационные потоки, внешние информационные объекты, функциональные блоки, функциональные модули, аналитические функции, а также методы, информационные системы и процессы обработки управленческой информации.

Формирование частных информационно-логических моделей для конкретных организаций целесообразно осуществлять на основе референтных моделей, путем их конкретизации и детализации. Кчислу референтных относится базовая (обобщенная) информационно-логическая модель, отражающая наиболее общие характеристики всех предприятий и организаций, независимо от их типов и отраслевой принадлежности.

Процедура перехода от базовой информационно-логической модели к частной предусматривает четыре этапа.

На первом этапе осуществляется детализация укрупненных информационных потоков: каждый из укрупненных информационных потоков базовой модели разбивается на более детальные потоки, учитывающие особенности конкретной организации. Детализация осуществляется с учетом типов и источников информации, а также ее принадлежности к определенным подразделениям, бизнессегментам и географическим сегментам. На втором этапе выявляются связи между входами и выходами функциональных модулей, на этой основе формируются предварительные (т.е. нуждающиеся в дополнительном уточнении) аналитические функции. На третьем этапе производится определение процессов сбора, хранения и обработки управленческой информации, которые протекают в рамках предварительных аналитических функций. Наконеи, на четвертом этапе происходит формирование окончательных аналитических функций, путем детализации и реорганизации определенных ранее предварительных функций.

В работе также указывается на возможность альтернативного подхода, при котором построение частной модели начинается с определения аналитических функций.

Ключевые слова: система управления эффективностью, информационно-логическое моделирование, референтная модель, частная модель, аналитическая функция, информационный поток, обработка управленческой информации.

Цитирование: Isaev D.V. Formation of individual infological models of performance management systems // Business Informatics. 2015. No. 4 (34). P. 32-37. DOI: 10.17323/1998-0663.2015.4.32.37.

Литература

1. Ferreira A., Otley D. The design and use of performance management systems: An extended framework for analysis // Management Accounting Research. 2009. No.20. P. 263-282.

2. Cokins G. Performance management: Finding the missing pieces (to close the intelligence gap). Hoboken, NJ: John Wiley \& Sons, 2004. 304 p.

3. The strategy gap: Leveraging technology to execute winning strategies / M. Coveney [et al.]. Hoboken, NJ: John Wiley \& Sons, 2003.240 p.

4. Eckerson W.W. Performance dashboards: Measuring, monitoring and managing your business. Hoboken, NJ: John Wiley \& Sons, 2006. 318 p.

5. Исаев Д.В. Проектирование систем информационной поддержки корпоративного управления и стратегического менеджмента // Аудит и финансовый анализ. 2013. №6. С. 329-334.

6. Isaev D. Performance management information support system: A conceptual model // European Journal of Economics, Finance and Administrative Sciences. 2012. No. 52. P. 6-20. 